\title{
DIE LIEFDE VAN GOD AS AANKNOPINGSPUNT VIR 'N GESPREK MET MOSLEMS: DIE ROL VAN JOH. 3:16. ${ }^{1}$
}

THE LOVE OF GOD AS POINT OF CONTACT IN THE DIALOGUE WITH MUSLIMS: THE ROLE OF JOHN 3:16 1

\begin{abstract}
Christian and Muslim relations are under tremendous strain. The political situation makes it very difficult to proclaim the love of God to Muslims. It is, however, possible to reach out to Muslims from the explanation of the love of God. John 3:16 is of utmost importance in this regard. In this article the love of God for the whole world is portrayed and in his love He reaches out to all and not only to Israel. The difficult concept of "Son of God" must, however, be explained to Muslims who often are offended by the concept because of a biological understanding of it. The confession of the Trinity is of importance to fully explain the love of God and must be proclaimed in the dialogue with and the proclamation of the Gospel to Muslims.
\end{abstract}

\section{INLEIDING}

Die verhouding tussen Christene en Moslems het sedert die aanval van 11 September 2001 op die World Trade Centre in New York onder ernstige druk gekom. Die spanning tussen hierdie twee groepe word vererger deur die huidige krisis in Israel. Die oorlog teen terrorisme en die wyse waarop dit deur die Amerikaners en hul bondgenote hanteer word, word dikwels deur die Moslems veralgemeen as die wyse waarop alle Christene jeens hulle optree. Is dit dalk steeds moontlik om die Evangelie van Christus aan Moslems te verkondig? Hóé dit gedoen moet word en op watter wyse die Evangelie van Christus aan Moslems verkondig kan word, sonder om 'n Westers-politieke kleur daaraan

$1 \quad$ Hierdie artikel word aan Prof. Faan Riekert aangebied met groot waardering vir sy besondere bydrae aan die Fakulteit Teologie, UV, in besonder met die vestiging van Religiekunde as vak.

Prof. P. Verster, Departement Sendingwetenskap, Universiteit van die Vrystaat, Bloemfontein. 
Verster Die liefde van God as aanknopingspunt vir 'n gesprek met Moslems

te gee, moet egter ook gevra word. So dikwels veroorsaak politieke oorwegings spanning wat tot misverstand en wanpersepsies lei. Johannes 3:16 is in dié verband 'n deurslaggewende teks: "God het die wêreld so liefgehad dat Hy sy enigste Seun gegee het, sodat dié wat in Hom glo, nie verlore sal gaan nie maar die ewige lewe sal hê."

\section{METODOLOGIE EN UITGANGSPUNTE}

Wat is die implikasies van die feit dat God liefde is en Joh.3:16 in dié verband vir die gesprek met Moslems? Sou Joh.3:16 'n teksgedeelte wees wat onmiddellik weersin by Moslems wek omdat daar sprake is van die Seun van God en dit binne die kader van die Islam nie aanvaarbaar is nie? 'n Ander vraag weer: Sou daar vanuit die liefde van God na Moslems uitgereik kon word en vanuit hierdie teks bepaalde grondslae gelê kon word om die liefde van God vas te stel en dan ook Moslems te bereik? Ten eerste moet na die implikasies van die liefde van God verwys word en Joh. 3:16 moet ontleed word. Deeglike eksegese is noodsaaklik om te verstaan wat die funksie van die teksgedeelte binne die Skrif is. Die teologiese en veral die missiologiese implikasies van die teksgedeelte moet dan verder ontleed word. Hoe die Islam in die algemeen reageer op hoofsake wat in die teksgedeelte na vore kom, moet vervolgens ontleed word. Die missiologiese betekenis van die teks in die gesprek met die Islam is dan van belang. Daar bestaan natuurlik verskeie verskillende menings binne die Islam maar ten opsigte van hulle sentrale belydenis wat hier van groot belang is, is daar wel 'n groter mate van eenstemmigheid (vgl. Ghassany 2002:310).

Die missiologiese raamwerk waarbinne die gesprek hier gevoer word, word bepaal deur die uitgangspunt dat God Hom wel in die Bybel openbaar. God self maak Homself bekend. Hierdie openbaring vind sy kulminasie in Jesus, die Here, die Woord van God. In enige gesprek sal die uitgangspunt dat God in Jesus Christus spreek wel van groot belang wees. Om dit te erken sluit nie die gesprek af nie, maar open juis moontlikhede om eerlik na mekaar te luister. Dialoog word nie gevoer sonder om ook bepaalde uitgangspunte duidelik te stel nie. Onder afdeling 4.1 word verder verduidelik hoe die proses van dialoog moet verloop. 


\section{DIE LIEFDE VAN GOD AS UITGANGSPUNT}

\subsection{Die God van Liefde, liefde tot God en liefde tot die naaste}

Wanneer die gesprek met Moslems aangepak word, is die saak aangaande die liefde van God van groot belang. Die Bybel beklemtoon in geen onduidelike taal nie die feit dat God liefde is. Dit is 'n sentrale uitgangspunt in die Christelike geloof. Joh. 3:16 speel in dié verband 'n wesenlike rol. Dat God liefde is, word uitgedruk in sy teenwoordigheid in sy Seun Jesus Christus. Die eis van liefde tot God en liefde tot die naaste as die sentrale saak in God se gebooie beklemtoon weer dat die mens op God se liefde moet antwoord.

Migliori (2008:312 e.v.) toon aan dat die liefdesgebooie juis die deur tot'n gesprek met die Moslems kan oopmaak. Hy verwys na die uitnodiging tot gesprek in die dokument: "A common word between Us and You" wat op 13 Oktober 2007 deur 138 Moslem-leiers en -geleerdes aan Christen-leiers dwarsoor die wêreld gerig is. Hulle dui aan dat daar nie sonder vrede en geregtigheid tussen die Moslem- en Christen-gemeenskappe vrede op aarde kan wees nie. Liefde tot God en liefde tot die naaste word as uitganspunt gestel, omdat dit volgens hulle die grondslag in die religieuse tekste van sowel Moslems as Christene en Jode vorm. Migliori (2008:314) wil die uitnodiging aangryp en vanuit 'n benadering van 1) die lees van die Skrif, 2) die eenheid van God, 3) die verhouding van liefde tot God en liefde tot die naaste en 4) die grondslae van intergeloofdialoog en samewerking die debat voer. In enige dialoog wys Migliori (2008:316) daarop dat bevestig moet word dat die Christelike uitgangspunt baie duidelik is dat God nie alleen liefde eis nie, maar dat Hy ook liefde ís wat die diepste van sy wese bepaal. Hy (2008:323) verwys na Rowan Williams wat verduidelik dat Christene dit baie duidelik aan Moslems moet maak dat hulle nie 'n biologiese Drie-Eenheid aanvaar nie. Christene sal egter onbeskaamd moet aantoon dat die selfgewende liefde wat in die diens, kruisiging en opstanding van Jesus voorkom een is met die liefde van God self. Migliori (2008:324) verduidelik:

We can continue along the lines of Williams's remarks by saying that when Christians affirm that the love of God cannot be separated from the crucified and risen Jesus, they do not 'associate' something other than God with God. Rather, they confess that the one and only God who is perfect love in all eternity puts himself at risk for the sake of communion with his creatures and enters the brokenness and estrangement of human life to renew it from within.

So word God se liefde in Jesus Christus uitgespel: nie as naakte mag nie, maar as almagtige liefde wat vryelik gee vir ander; daardie mag wat aan die werk was in Jesus se lewe, dood en opstanding omdat dit God se eie lyding en liefde veronderstel wat tog oorwin het (Migliori 2008:324). 
Verster Die liefde van God as aanknopingspunt vir 'n gesprek met Moslems

Dit is dus duidelik dat die liefde van God as sentrale saak in die gesprek met Moslems wel na vore moet kom. Die rol wat Joh. 3:16 in dié verband kan speel moet nou verder ondersoek word.

\subsection{Die implikasies van Johannes 3:16}

\subsubsection{Eksegetiese uitgangspunte}

Schnackenburg (1984:361) is van mening dat dié gedeelte (Johannes 3:13-21) 'n kerugmatiese uiteensetting van die Evangelies is en as samevatting van die Evangelie dien. ${ }^{2}$ Die implikasies is van groot belang. Om sodanige teksgedeelte te ontleed, kan die aktante en hulle rol in die teksgedeelte ontleed word. In die eerste plek moet gekyk word na die verskillende aktante in die gebeure wat hier beskryf word (vgl. Van Wolde 1989:80-118). God is die primêre aktant. Hy is die een wat die wêreld, die kosmos, so liefhet dat Hy sy enigste Seun, die aktant wat met God in verband staan, gegee het sodat die wat in God glo of in die Seun glo, nie verlore sal gaan nie, maar die ewige lewe sal hê. Ten opsigte van hierdie teks is die eerste belangrike vraag hoe God, as aktant, liefde teenoor die wêreld betuig. Botha en Rousseau (2005:1149 e.v.) is van mening dat die wêreld in hierdie verband na die Joodse wêreld verwys en dat dit nie in die algemeen verstaan kan word as sou God die hele wêreld in al sy verskillende verbande en persone so liefhet dat Hy sy Seun gegee het nie. Botha en Rousseau (2005:1149 e.v.) grond hulle oortuiging op eksegetiese, literêre en sosio-wetenskaplike getuienisse. Hulle lê klem op die verhouding tussen God en die Jode wat dan as sy volk daartoe gelei word om in Christus te glo en om Hom lief te hê. Dit sou dan beteken dat die klem van hierdie gedeelte nie lê op die universele heil wat in Christus Jesus na mense uitreik nie, maar wel op die feit dat God Israel liefhet en juis wil hê dat Israel na Hom moet terugkeer. Die beklemtoning hiervan maak dit dan moontlik om in die lig van die Johannesevangelie God voor te hou as die een wat na Israel uitreik. Botha en Rousseau (2005:1167) bevestig hulle uitgangspunt soos volg:

The grammatical, literary, historical and social science reading of the verse we presented above have all from different perspectives confirmed that what is at stake in John 3:16, namely Jesus' coming to Is-

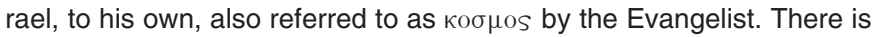

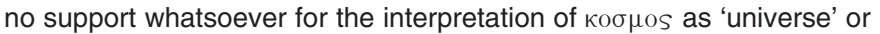
'all humanity' or 'world in general' in this verse. The various readings

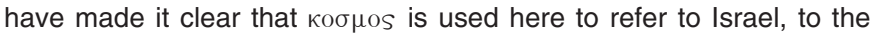

2 Van Tilborg (1993:3 e.v.) lees Johannes vanuit 'n narratiewe perspektief en verstaan die wyse waarop die liefde, veral binne familieverband, as uiters belangrik aangedui word. 
group with whom God have had dealings for a long time and who stand in a client relationship to God's patronage.

Daar is egter verskeie ander opmerkings wat gemaak moet word en aanduidings dat dit nie so aanvaar kan word nie. Eksegeties sou dit uiters vreemd wees as "Israel" nie eksplisiet gebruik word wanneer na Israel verwys word nie. Die liefde word beklemtoon wat op sigself reeds universeel aandoen. коouos word wel ook universeel aangewend, beide in Johannes en in die Grieks

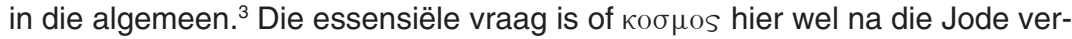

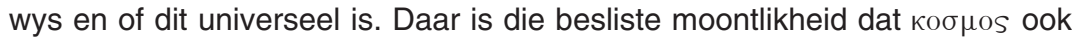
universeel aangewend kan word en dit sou in die lig van die boodskap van die Evangelie en die Nuwe Testament oor die algemeen 'n meer logiese lees van die teks wees. Die talle negatiewe verwysings na Jode in Johannes bevestig dat dit onwaarskynlik is dat die kosmos net op hulle dui. Die boodskap van God se goeie nuus wat Botha en Rousseau (2005:1151) erken, maak die universele lees van die teks wel moontlik. "God het die wêreld so liefgehad" dui uitdruklik op 'n universele heil wat deur God vir die wêreld aangebied word. ${ }^{4}$

3 Louw \& Nida (1988:107, nota 9.23 ) verwys daarna dat die figuratiewe uitbreiding van kosmos wel mense aandui, maar dan mense van die wêreld.

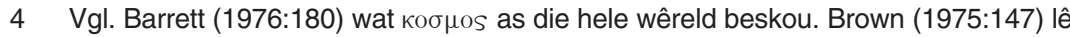
ook 'n verband tussen die universele betekenis van Abraham se offer (van sy seun) vir die wêreld en die universele heil in die gedeelte. Vgl. ook Lindars (1972:159) vir'n soortgelyke verwysing. Schnackenburg (1984:399) laat geen twyfel dat die wêreld die sondige mensheid is wat van God weggekeer het en dat die wêreld die objek van God se liefde is nie. Lincoln (2005:154) beskryf dit as die wêreld in sy vervreemding van en vyandskap teen God: "God loves that which has become hostile to God." Ook Waetjen (2005:156), wat die konteks binne die raamwerk plaas van die gesprek met die Jode na 70 n.C., verwys na die universele implikasies van die begrip wêreld. Brodie (1993:199) beskryf dit as "...a weary world of faltering pelgrims..." Cook (1979:26) verwys na die antitese met die wêreld wat God se liefde net meer beklemtoon. Cassidy (1992:34) beklemtoon dat Jesus juis die Redder van die wêreld is en beklemtoon daarin ook die universele element van verlossing. Zahn (1983:206) verduidelik: "Die Liebesabsicht Gottes umfasst die ganze Menschheit." Milne (1993:77) is juis van mening dat die universele liefde van God vir die hele mensdom deur sy liefde vir Israel na vore kom. Beasley-Murray (1987:51) meen Johannes 3:16 is die fundamentele opsomming van die Evangelie: "Here alone in the Fourth Gospel the love of God for the rebellious world is stated to be the reasons for the incarnation and death of Christ; more characteristically love for the disciples and the evil of the world are stressed." Ook Houwelingen (1997:99) beklemtoon die feit dat God uitreik tot die hulpelose mensdom. Morris (1971:229) dui juis aan dat daar 'n verskil bestaan tussen die Joodse beskouing dat God Israel liefhet en die liefde vir die wêreld wat hier na vore kom: "It is a distinctively Christian idea that God's love is wide enough to embrace all mankind. His love is not confined to any national group or any spiritual elite. It is a love which proceeds from the fact that He is love (1 John 4:8,16). Selfs al maak Calvyn dit duidelik dat die liefde van God in Jesus Christus nie beteken dat 
Verster Die liefde van God as aanknopingspunt vir 'n gesprek met Moslems

Dit kom duidelik na vore wanneer in vers 17 gesê word dat God nie sy Seun na die wêreld toe gestuur het om die wêreld te veroordeel nie. Wêreld word hier in 'n sterk universele sin gebruik. God het dus nie veroordelend opgetree nie, maar wou juis deurdat Hy sy Seun gestuur het, die heil wat in die Seun is, na die wêreld toe bring. Daarom lê die klem by кобнos in die eerste plek nie soseer op die Joodse wêreld of op die Joodse volk van God nie, maar op die universele heil wat baie sterk in die Johannes-evangelie na vore kom. Wanneer ander sake soos die gesprek met die Samaritaanse vrou (Johannes 4) geneem word, is dit ook duidelik dat die heil duidelik baie wyer strek as bloot die Joodse volk. Inteendeel, die Jode word in die Johannes-evangelie dikwels geteken as mense wat juis nie die Evangelie wou aanvaar nie. Belangrik egter is ook die woorde - "so liefgehad". Jesus trek ook alle mense na Hom toe soos blyk uit Joh. 12:20-36. Barrett (1976:180) dui aan hoe essensieel die liefde is, maar ook dat dit beantwoord moet word:

Love seems to be, for John, a reciprocal relation. The Father loves the Son (3:35; 10:17; 15:9f.; 17:23f., 26), and the Son loves the Father (14:31); Jesus loves his own (11:5; 13:1, 23, 34; 14:21; 15:9(f.), 12; 21:7, 20), and his own love, or should love, one another (13:34f.; 15:12f.,17; 17:26). They must also love him (14:15, 21, 23f., 28; 21:15f.).

Brown (1975:133) lê groot klem daarop dat die koms van Jesus 'n uiterste daad - soos aangedui deur die aoristus — van liefde van God is. Kysar (1986:55) verbind die kruis en die liefde van God in die verhoging van die Seun. In die gesprek met Moslems sal dit baie belangrike woorde wees wat in so 'n gesprek na vore sal kom. Lincoln (2005:154) beskryf die liefde soos volg: "The greatness of the divine love is not simply an inspiring theological concept but is demonstrated in its gift, that of the only Son."

almal gered word nie, meen hy tog dat dit effektief voldoende vir almal is (vgl. Towne 2005:243 e.v.).

5 Waetjen (2005:156) verbind God se liefde met die beeld dat Jesus soos die slang verhoog sal word - 'n duidelike verwysing na die kruis waar Hy deur sy lyding sy liefde sal betoon. Ook Brodie (1993:198) beskryf dit soos volg: "On God's part too there is a form of death - the giving of an only child so that the world may be saved." Milne (1993:77) beklemtoon ook die diepte van die liefde van God in Jesus Christus: "The unfathomable depth of the love of God is stressed: God so loved... in his love, God went so far as to 'give (up)' his one and only Son (we should probably see here a reference to incarnation as well as crucifixion)." Smelink (1977:88) beklemtoon dat die Vader Homself in sy liefde in Christus gee. Ridderbos (1987:164) wys daarop dat die waarom van die weg van God se liefde nie bespreek word nie, maar wel die dat en die hoe groot. God keer in sy groot liefde tot die mens met 'n liefde wat tot die einde toe sal bestaan. 


\subsubsection{Die liefde van God en die Moslems}

By Moslems kom die konsep van God se liefde nie op dieselfde wyse voor as by die Christelike beskouing dat God liefde is nie. ${ }^{6}$ Volgens die Koran is God wel genadig en barmhartig (Sura 1). Die mens moet in hierdie verhouding met God wat genadig en barmhartig is, ' $n$ verhouding opbou waarin liefde wel ' $n$ rol speel. Daardie verhouding moet so hanteer word dat dit uiteindelik daartoe kan lei dat 'n soort balans verkry word en die mens in 'n verhouding met God kan kom. Starkey (1985:425 e.v.) toon aan dat die vraag na waarheid en openbaring belangrik is wanneer godsdienste met mekaar vergelyk word. Sy gaan van die standpunt uit dat die essensiële element in die Christelike godsdiens "agape"liefde is. Waarheid kom ook voor by ander oortuigings en godsdienste as hulle oor openbaring beskik wat 'n liefdesrespons teenoor ander verlang. Verwerplik is daardie ideologieë en godsdienste wat nie liefde verlang nie. Volgens haar is die sentrale openbaring van God dat Hy liefde is in sy Seun Christus. Die korrekte respons teenoor God se liefde is volgens haar nie die regte dogma nie, maar geloof wat in liefde na vore kom. Liefde tot God kan slegs na vore kom in die konkrete meegevoelige genadige aksie waarin die naaste beskou word as enigeen, ongeag godsdiens, nasionaliteit, geslag of sosiale posisie insluitende vyande. Starkey (1985:441 e.v.) meen dat Allah hom in die Koran openbaar as die genadige en barmhartige wat juis in die verhouding met mense liefde vereis. Starkey (1985:442) stel dit soos volg:

The Qur'an calls humankind to submit to God. Believers, or those who submit to God, are defined as those who do good to or love their neighbours. Confession of faith in Islam must be corroborated by fidelity of life. According to the Qur'an, God loves those who do good, and God does not love those who do evil (Suras 2/195, 3/134, 3/148, 5/96).

Nie-Moslems moet ook met liefde benader word. Starkey (1985:446) beklemtoon die feit dat Moslems van die oortuiging is dat God hulle slegs op hulle dade sal beoordeel en daarom is liefde belangrik. Alhoewel daar inderdaad elemente van liefde is en die eis tot naasteliefde na vore kom in die Islam, moet die wesenlike van die oortuiging dat God liefde is, duideliker vanuit die Evangelie oorgedra word. Hierin sou van Starkey verskil moet word en aangetoon word dat die liefde in 'n Christelike sin juis die totale radikale liefde van God vir

$6 \quad$ Kellerhals (1978:76) stel dit duidelik: "In der Tat ist die Botschaft von der Liebe Gottes im Islam unbekannt (darum ist auch der Begriff Barmherzigkeit von einem ganz andern Inhalt bestimmt und gefült." Bowker (2004:20) verwys egter wel daarna dat Moslems van die liefde van God praat. Daar is wel diegene wat meen dat die Koran tog die liefde van Allah beklemtoon en wel daarin dat Allah as die liefdevolle beskryf word. Naude (1974:44) stel dit soos volg: "Die mens ervaar die liefde van God in hierdie wêreld wanneer God hom tot redding kom". Hy bevestig egter ook dat dit meer indirek ter sprake kom (Naude 1974:47). 
Verster Die liefde van God as aanknopingspunt vir 'n gesprek met Moslems

sondaars is en dit terwyl hulle nog sondaars is. Die waarheid lê dus nie bloot in die ooreenkoms van liefde nie, maar in die openbaring van die wese van God as liefde wat slegs in Jesus Christus gevind kan word. Daar kan egter wel met Starkey saamgestem word dat die uitgangspunt van liefde onder mense gesprek met mekaar moontlik maak.

In die Johannes-evangelie word die groot klem hier op liefgehad geplaas sodat dit 'n buitengewone beklemtoning van God self is wat uitreik na die

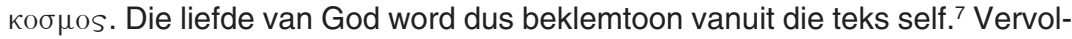
gens word beklemtoon dat Hy sy enigste Seun gegee het. Dat Hy sy enigste Seun gegee het, is natuurlik onmiddellik vir die Moslems en die Islam onaanvaarbaar. Dit dui daarop dat God in 'n relasie gekeer het tot iemand anders, en dat daardie persoon as sy Seun aangedui word.

\section{TEOLOGIESE EN MISSIOLOGIESE IMPLIKASIES}

\subsection{Dialoog en gesprek met Moslems}

Ghassany (2002:310) toon aan dat die verskil tussen Islam groepe, bv. Sunni en Sjhiet vervaag wanneer dit by die geloofsbelydenisse kom. Wat egter wel waar is, is dat beide groepe outoritêre én bevrydende oortuigings huldig. Sekere uitdagings bly in die proses van dialoog van belang. Daar is gematigde Moslems wat die heilige geskrifte van die Islam op 'n subtiele en redelike wyse benader en daarom ook die modern benadering van die waarde van mense beklemtoon. Radikale Moslems lees aan die ander kant die geskrifte steeds letterlik en is geneig tot oppervlakkige interpretasies (Riddell \& Cotterell 2003:192). Schudder (2008:78) toon aan dat dit moontlik is om die saak van verdraagsaamheid vanuit Moslem-bronne te beklemtoon. Aasi (2006:221222) verwys na sake soos om algemene wanvoorstellings en wanopvattings te oorkom, om die probleem van verteenwoordigers in die proses van dialoog se status in hulle geloofsgemeenskappe te verreken (binne Rooms-katolieke kringe is dit makliker omdat daar duidelike hiërargie en reëls vir deelname is) en om verskille in oogmerke en doelwitte te oorkom.

Ayoub (2004:314-316) verwys na korttermyn- en langtermyndoelwitte in dialoogvoering. Volgens hom moet daar gestreef word na wedersydse erkenning van legitimiteit en egtheid van die verskillende geloofstradisies. Daar moet egter ook gestreef word na egte en ware respek vir die geloof van die ander, insluitende geloofsoortuigings, etiese beginsels, sosiale waardes en politieke verwagtings en aspirasies. Deelnemers in die dialoog moet as gelyke

7 Calian (1986:121) wys op die radikale uitdaging wat Joh. 3:16 vir die kerk stel in die taak om by mense in nood betrokke te raak. 
vennote beskou word. Tradisies moet verder vir hulle self spreek eerder as om die lens van die geloofsoortuiging te gebruik om die ander te beoordeel. In stede daarvan om ander tradisies vanuit jou eie geskrifte en tradisies te beoordeel, moet die eie geskrifte van die ander geloofstradisie self beoordeel word. Verder is objektiwiteit en regverdigheid van groot belang.

McCloud (2004:337) verwys na die ingewikkelde aspek van dialoog en hoe bepaalde vooropgestelde idees dit soms uiters moeilik vir groepe maak om mekaar in die proses van dialoog te vind.

Takim (2004:347) stel die uitdaging vir dialoog soos volg:

Dialogue is the first step toward accommodating or making space within oneself for the other. The challenge for both Muslims and Christians when they converse is to seek opportunities for interpretations that can make a community see the enemy in a new way. It is essential that we move away from defining ourselves over and above an enemy 'other'. This is an important measure in establishing a peaceful relationship. In this sense, I believe we need to go beyond tolerating or understanding the other. More than ever, there is a need to embrace the other. This suggests a different function of dialogue, one that can bring the hearts, rather than just the minds, of people together.

Die grondslag van dialoog sluit sake soos respek, regverdigheid en goedhartigheid in. Werklike verskille mag egter nie ontken word nie:

Muslims should not be expected to relinquish their affirmation of the unity of God, and Christians should not be expected to give up their affirmation of the depth and richness of the love of the one triune God for the sake of a superficial harmony (Migliori 2008:328).

Migliori (2008:330) verwys ook na Moltmann wat drie voorvereistes vir vrugbare dialoog stel:

... first, there must be a life-threatening conflict in which the possibility of serious dialogue offers hope; second, all participants must engage in the dialogue as committed representatives of their own faith tradition, not pretending to be other than they are for the sake of easy paper resolutions; and third, the dialogue must be undertaken for the sake of truth that serves life, not simply for its own sake.

Bos (2008:44 e.v.) beklemtoon dat die missionale kerk nie radikaal teenoor interreligieuse kontak en samewerking staan nie. Die gereformeerde beskouing maak dit volgens hom juis moontlik om te verstaan dat mense ongeag hulle religieuse beskouing oor gawes beskik om in God se skepping te dien. 
Verster Die liefde van God as aanknopingspunt vir 'n gesprek met Moslems

Wessels (1978:114) is van mening dat in die gesprek tussen Christen en Moslem dit wel om Christus moet gaan, maar dat die gesprek nie daarin moet opgaan nie. Wessels (1978:129) meen ook dat om die godheid van Christus te oorbeklemtoon sonder om ook sy mensheid in ag te neem tot 'n skeeftrekking kan lei wat in die gesprek met Moslems verkeerd verstaan kan word. Wessels (1978:131) verduidelik dat daar nie volledige identiteit van Vader en Seun is nie, maar dat 'n unieke belydenis dat God in Christus spreek, uitgedruk word. Dialoog of getuienis loop telkens anders in 'n unieke proses en moet daarom altyd binne bepaalde omstandighede die situasie in ag neem. Soms is daar radikale verharding van bepaalde groepe, maar aan die ander kant kan daar groot openheid wees om met mekaar in gesprek te tree (Wessels 1978:137). Ten opsigte van Wessels se beskouing oor die eenheid tussen Vader en Seun moet verskil word. Die eenheid is juis 'n synseenheid in die verhouding tussen Vader en Seun wat in die dialoog ook wel verreken moet word.

\subsection{Missiologiese implikasies van belydenisse}

Die bekende belydenis van die Islam, naamlik dat Allah die enigste God is en dat Hy alleen as God erken moet word, maak nie die moontlikheid oop vir so 'n verhouding met 'n persoon wat as sy Seun aangedui kan word nie. In die gesprek met Moslems sal daar dus verduidelik moet word wat verstaan word onder enigste Seun en watter verhouding daar tussen die Vader en Seun beskryf word wanneer van die enigste Seun gepraat word. Die Drie-eenheid kom hier ter sprake. Vir die Moslem is die Drie-eenheid 'n verwerplike gedagte soos in verskeie suras na vore kom. Vir die Christen is dit die kulminasiepunt van die heerlikheid van die Openbaring van God. God het sy enigste Seun gegee. ${ }^{8}$ Natuurlik is daar verskillende interpretasies van die Drie-eenheid. Die Drie-eenheid word soms as 'n relasionele eenheid gesien waar Vader, Seun en Heilige Gees eerder in relasie tot mekaar staan as wat dit 'n Synseenheid is waar Vader, Seun en Heilige Gees in die syn van hulle bestaan tot mekaar bestaan. Die beklemtoning van die Synseenheid - Vader, Seun en Heilige Gees - in 'n synseenheidverhouding tot mekaar, is van groot belang, want in hierdie verhouding tot mekaar tree hulle tot die wêreld toe om die wêreld te verlos. Die enigste Seun van God word hier op 'n unieke wyse aangedui, sodat die

8 Barrett (1976:180) dui aan dat uios slegs in Johannes vir Jesus gebruik word en op die uniekheid van die verhouding tussen Vader en Seun dui. Schnackenburg (1984:400) stel dit soos volg: "The only-begotten is also the uniquely loved. It is this Son, most intimately united to him and supremely loved, his own and only Son, that God has given to the world to snatch it from destruction." Cook (1979:43) beklemtoon die uniekheid van die enigste Seun en verkies om nie klem op die "gebore" te lê nie. Ook Louw en Nida (1988:591, nota 58.52) meen dat die klem op unieke lê en nie op gebore nie. 
verhouding tussen Vader en Seun in Johannes 3:16 na vore tree. Die volgende saak wat aan die orde kom, is die saak dat die wat in Hom glo die ewige lewe sal kry. Geloof word hier dus gestel as die wyse waarop daar in 'n verhouding met God getree word deur sy Seun Jesus Christus. Die wat dan glo, sal nie verlore gaan nie, maar die ewige lewe hê. Dit beteken dat hulle reeds onmiddellik wanneer hulle in God glo uit die duisternis sal kom na God se wonderbare lig en in die lig die heerlikheid van God sal ondervind. Hulle sal nie verlore gaan nie. Geloof is dus 'n erkenning dat Jesus Christus die Seun van God is en deur die geloof in Hom word die heil verkry. Vers 17 beklemtoon eweneens dat die wêreld deur die Seun gered kan word. Daarom het God die Seun gestuur sodat die wat volgens vers 18 glo, nie veroordeel word nie, maar die wat nie glo nie, reeds veroordeel is omdat hulle nie in die Enigste Seun van God glo nie. In die gesprek met die Moslems sal dit ook 'n uiters belangrike saak wees wat telkemale na vore tree. In die lig hiervan moet die vraag nou gevra word of daar inderdaad gesprek met Moslems moontlik is en op watter vlak so 'n gesprek met Moslems gevoer moet word. Dit moet baie duidelik gestel word dat gesprek nie maar net op die vlak van oppervlakkige medemenslikheid gevoer word nie. Medemenslikheid kan ter sprake kom wanneer dit binne 'n duidelike teologiese raam geplaas word. Die belydenis van die Christen is juis dat die heil in Christus Jesus te vinde is, teenoor die Moslems se belydenis dat Allah alleen bestaan en dat Hy alleen oor mense se lewens beskik.

\section{ISLAM-OORTUIGINGS}

Dit is voorts ook van belang om te vra wat die Moslems oor Jesus Christus glo. Dit is duidelik dat sekere kernelemente van die belydenis aangaande Christus in Christelike verband nie erken word nie. Schumann (2002:29) dui aan dat Jesus deur die Islam as 'n unieke profeet erken word:

Jesus is different from the other prophets, including Muhammad, in only one way. Not only does he perform signs, he is a sign from God. God uses him to direct the attention of human beings to Himself and assure them that $\mathrm{He}$ intends to deal mercifully with them (Q.19:21)... Muhammad saw Jesus as a living testimony to God's creative power and hence to God himself, and this was in turn possible only because he (Muhammad) has adopted the belief in the virgin birth.

Jesus Christus word as profeet erken. Sy maagdelike ontvangenis word erken. Sy wonderwerke word erken, maar die hele kruisgebeure, die soenverdienste van die kruisgebeure word totaal misken. Die verlossing in Christus wat aan die kruis plaasvind, word deur die Islam afgewys en nie as 'n moontlike wyse van verlossing erken nie. Verder is dit ook van belang dat die Islam enige moontlikheid om die absolute eenheid van God te misken, van die hand 
Verster Die liefde van God as aanknopingspunt vir 'n gesprek met Moslems

wys. Die eenheid van God is absoluut en daar kan geen sprake wees dat God in bepaalde verband met enigiemand kan tree nie. ${ }^{9}$ God self is die een wat die absolute eenheid beklemtoon. Hy is die EEN vanuit wie die absolute eenheid kom. Gesprek sou egter wel moontlik kon wees wanneer verstaan word dat die Drie-eenheid nie die eenheid van God misken nie, maar dat die intertrinitariese element van die versoening en verlossing juis deur die eenheid van God beklemtoon word.

Vanuit die Islam-wêreld word ernstige vrae gevra rondom die hele saak van die Seun van God, of dit hoegenaamd moontlik is om te praat van die Seun van God. ${ }^{10}$ Die Johannes-evangelie maak 'n baie sterk saak daarvoor uit dat Jesus Christus van die begin af God was. Hy was in die begin by God en Hy was self God. Alles het deur Hom tot stand gekom. Die groot beklemtoning van Jesus se heerlikheid word dus op 'n baie besondere wyse erken en bevestig. Daarmee saam hang die talle "Ek is"-uitsprake in die Johannes-evangelie wat daarop dui dat Jesus op dieselfde vlak is as JAHWE wat as "is wat Hy is" bekend staan. ${ }^{11}$ Dit is dus moontlik om vanuit die teks die besondere uniekheid van Jesus Christus te erken, ook in die gesprek met die Islam. Daarom sou daar vanuit Johannes 3:16 wel 'n saak vir die besondere ingryping van God in die werklikheid uitgemaak kon word, en hierin sou die liefde van God na vore kon kom.

In 'n belangrike artikel wys Brown (2007:422 e.v.) daarop dat die begrip "Seun van God" uit die staanspoor groot weersin by Moslems wek. Die oomblik wanneer daar byvoorbeeld in die Nuwe Testament gelees word dat Jesus

9 Kellerhals (1978:73) wys op die fundamentele aard van die eenheid van God in Islam (vgl. Sura 112:1-4). Khan (2004:42) verwys ook na die enigheid van Allah op grond van dieselfde verwysing: "Allah: there is no God but Him, the Living, the Eternal One." Brown (2004:139) druk dit soos volg uit: "The essence of God is his eternal oneness, and all of his other qualities are subordinate." Vgl. ook Martin (1982:4): "Muslim theologians sought arguments, both from scripture and through reason, to make persuasive the fundamental oneness and unity of Allah, to the exclusion of other "lesser" gods or plural implications of a "godhead" that threatened that unity." Cragg en Speight (1988:7) wys op die begronding van die bestaan van Moslems in die eenheid van Allah. Fyzee (1981:18) beklemtoon dat daar geen kompromis oor die eenheid van God - absolute monoteïsme - kan wees nie. Ook Hamidullah (1983:50) wys daarop dat Moslems geen verhouding het met hulle " ...who associate others with the One God" nie. Haneef $(1985: 11)$ toon aan dat die eenheid van Allah al die ander eienskappe oortref. Esposito (1991:24) verduidelik volledig: "God is not a Trinity (5:76); He has no begotten son (2:116) nor daughters nor consorts (6:100-01); and finally, unlike the religion of pre-Islamic Arabia, God has no partners or associate deities (6:22-24)."

10 Khan (2004:42) wys op die radikale wyse waarop dit verstaan word. "God does not forgive partners being ascribed to him. He forgives whom He will all other sins. Whoever ascribes partners to God has strayed far from the truth $(4: 116)$."

11 Kyk Brown (1975: 533-538) vir 'n volledige bespreking van die "Ek is"-uitsprake. 
die "Seun van God" is, verwerp die Moslem vanuit sy of haar agtergrond die hele boodskap. Brown (2007:423) verwys na D.A. Chowdhury wat aandui dat die biologiese element baie sterk vir Moslems na vore kom en dus in geheel verwerp word. Aanvaarding of selfs net die lees van die begrip kan Moslems reeds tot ongeloof in die Islam en gevolglik tot die verderf lei. Die teologiese konsep in die oorspronklike word nie deur vertalings weergegee nie en juis daarom is die verset teen die begrip by Moslems so groot. Pogings tot ' $n$ oplossing word veral deur vertalers gesoek met vertalings waar die begrip "Seun van God" vervang word met begrippe soos "God se geliefde" of "God se ewige Woord" (Brown 2007:426). Soms word die metaforiese invertaal, byvoorbeeld die "Christus vir wie God so liefhet soos sy Seun", of die begrip word vergeestelik deur "die geestelike Seun van God". Soms word die term in Hebreeus geplaas, "ben Elohim" of met 'n voetnoot verduidelik (Brown 2007:427). Brown (2007:429) se gevolgtrekking is dat Moslems nie so geslote vir die Evangelie is soos soms gemeen word nie, maar dat hulle tog wel aanstoot neem teen die wyse waarop die begrip "Seun van God" oorgedra word. Johannes 3:16 gebruik dit wel. Dit kan dus beteken dat die teksgedeelte nuut vertaal sal moet word om die liefde van God te verduidelik en oor te dra sonder om die betekenis van die begrip te misken. Die liefde wat dan beklemtoon word deur die wyse waarop God uit Homself tree en betrokke raak by mense is dus van groot belang. God is die een wat radikaal betrokke is by mense in hulle bestaan. Vanuit hierdie betrokkenheid by die bestaan van mense sou die liefde van God en ook die liefde onder mense beklemtoon kon word, en sou die besondere betekenis van die liefde van God en die liefde vir mense na vore gebring kon word.

\section{MISSIOLOGIESE IMPLIKASIES}

Dit beteken dat in die moderne omstandighede waar groot spanning heers, die politieke verstaan van die Evangelie verruil moet word vir 'n verstaan van die Evangelie vanuit die liefde van God. Konsensus rondom die liefde van God moet gesoek word in dialoog. Daar moet daarna gestreef word om wel moontlike aanduidings van die liefde van God in die Islam te vind en daarop voort te bou. Die Christologiese implikasies van die Evangelie van liefde moet na vore gebring word en die Christologiese diepte van die verhouding van God tot die mens waarin die liefde van God uitmond, moet na vore gebring word. In hierdie verband is die intertrinitariese verstaan van die heilsgebeure van groot belang en moet dit beklemtoon word. Alleen vanuit die intertrinitariese verstaan kan die volheid van die Evangelie duidelik verstaan word. In die gesprek met die Islam sal hierdie sake na vore gebring moet word. Die Christene sal in gebrokenheid, maar ook met 'n duidelike antwoord, die liefde van God moet begrond in die intertrinitariese heil wat na vore kom. Die liefde 
Verster Die liefde van God as aanknopingspunt vir 'n gesprek met Moslems

van God staan nie los van die intertrinitariese implikasies nie en die liefde van God moet juis in die lig daarvan aan Moslems verduidelik word. Dit sou kon beteken dat daar ingrypende implikasies is vir die verkondiging van die Evangelie. Die Evangelie word dus vanuit die diepte van die verhouding tussen God en sy Seun verkondig. Naude (1974:48) wys daarop dat daar 'n behoefte aan die liefde van God is: "Ons kan dus sê dat die Moslem 'n behoefte het aan die egte, opsoekende liefde van God wat ons deel geword het in Jesus Christus."

Jonker (1974:150) laat geen twyfel dat die sentrale belydenis rondom Jesus essensieel is nie: "In die ontmoeting met die Moslem sal die Christen probeer om hom bekend te stel met Jesus en teenoor hom te getuig van wie Jesus werklik is."

Jonker (1974:172) skryf verhelderend oor Jesus en die liefde van God:

Die redding wat Hy (Jesus - PV) bring, beteken dat Hy juis aan sulke mense die versekering gee: julle is vergewe, julle word aanvaar. Daarin maak Hy Gods liefde onder mense tasbaar, dat Hy die mens vir ander mense is en dat in Hom God sy hand genesend, verlossend, aanvaardend op mense lê.

\section{SLOT}

Johannes 3:16 bied besondere betekenis vir die verstaan van die Evangelie en die uitdra van die Evangelie in die Moslem-wêreld. Alleen vanuit die verstaan van God in sy Triniteit kan die liefde van God volkome begryp word. Alleen so kan verstaan word dat God in sy Triniteit liefde is en ook in Hom geglo kan word. Dit beteken egter dat begrippe wat die betekenis daarvan onduidelik maak, goed verduidelik sal moet word. Die liefde van God moet straal uit die belydenis van die kennis van God en die lewe met God. 


\section{BIBLIOGRAFIE}

AASI, G-H.

2006. Christian-Muslim dialogue in the United States: A Muslim perspective. Currents in Theology and Mission 33(3):213-222.

AyouB, M.

2004. Christian-Muslim dialogue: Goals and obstacles. The Muslim World 94 (July): 313-319.

BARRETT, C.K.

1976. The Gospel according to John: An introduction with commentary and notes on the Greek text. London: S.P.C.K.

Beasley-Murray, G.R.

1987. John. (Word Biblical Commentaries). Waco, Texas: Word Books.

Bos, M.S.

2008. Christian-Muslim relations: Testing our credibility. Reformed Review 61(2) (online):44-51.

Botha, J.E. \& Rousseau, P.A.

2005. For God did so love the whole world - only Israel! John 3:16 revisited. HTS Teologiese Studies 61(4) (November):1149-1168.

BOWKER, J.

2004. What Muslims believe. Oxford: Oneworld.

BRODIE, T.L.

1993. The Gospel according to St. John: A literary and theological commentary. Oxford: Oxford University Press.

BRown, D.

2004. A new introduction to Islam. Malden, Ma.: Blackwell.

BRown, R.

2007. Why Muslims are repelled by the term "Son of God". Evangelical Missions Quarterly 43(4):422-429.

BROWN, R.E.

1975. The Gospel according to John. I-XII. The Anchor Bible. London: Geoffrey Chapman.

CALIAN, C.S.

1986. The challenge of John 3:16 for theological education. The Christian Century February 5-12:121, 145-148.

CAssidY, R.J.

1992. John's Gospel in new perspective. Maryknoll, New York: Orbis.

Cook, W.R.

1979. The theology of John. Chicago: Moody. 
Verster Die liefde van God as aanknopingspunt vir 'n gesprek met Moslems

Cragg, K. \& Speight, R.M.

1988. The house of Islam. Third edition. Belmont, Ca.: Wadsworth.

EsPosito, J.L.

1991. Islam: the straight path. Expanded edition. New York: Oxford University Press.

FyZEE. A.A.A.

1981. A modern approach to Islam. Delhi: Oxford University Press.

GHASSANY, H

2002. The calls of Kairos and Islam. Islam and Christian-Muslim Relations 13(3):303313.

HAMIDULLAH, D.

1983. Introduction to Islam. Fifth edition. Lahore, Pakistan: Sh. Muhammad Ashraf.

HANEeF, S.

1985. What everyone should know about Islam and Muslims. Lahore, Pakistan: Kazi Publications.

HouWELINGEN, P.H.R.

1997. Johannes: Het Evangelie van het Woord. Kampen: Kok.

JONKER, W.D.

1974. Jesus, meer as 'n profeet: In gesprek met Islam oor die Moslem belydenis. Bloemfontein: NG Sendingpers.

Kellerhals, E.

1978. Der Islam: Seine Geschichte, seine Lehre, sein Wesen. Gütersloh: Gütersloher Verlagshaus Mohn.

KHAN, M.W. 2004. Introducing Islam: A simple introduction to Islam. New Delhi: Goodword Books.

KYSAR, R.

1986. John. Minneapolis: Augsburg. Augsburg Commentary on the New Testament.

LINCOLN, A.T.

2005. The Gospel according to St. John. (Blacks New Testament Commentaries). London: Continuum.

LINDARS, B.

1972. The Gospel of John. Grand Rapids, Mi.: Eerdmans. The New Century Bible Commentary.

Louw, J.P. \& NidA, E.A. (Eds).

1988. Greek-English lexicon of the New Testament based on semantic domains. Volume 1. (Introduction and domains.) New York: UBS.

MARTIN, R.C.

1982. Islam: a cultural perspective. Englewood Cliffs, N.J.: Prentice-Hall. 
McCloud, A

2004. Refections on dialogue. The Muslim World 94 (July):335-341.

MIGLIORI, D.L.

2008. The love commandments: An opening for Christian-Muslim dialogue. Theology Today 65: 312-330.

MILNE, B.

1993. The message of John. Here is your king! Leicester: Inter-Varsity.

MoRRIS, L.

1971. The Gospel according to John. Grand Rapids, Mi.: Eerdmans. New International Commentary on the New Testament.

NAUDE, J.A.

1974. Daar is geen God naas Allah nie: In gesprek met Islam oor die Moslem belydenis. Bloemfontein: NG Sendingpers.

Riddell P.G. \& Cotterell P.

2003. Islam in context: Past, present, and future. Grand Rapids. Mi.:Baker Academic.

RidDERBOS, $\mathrm{H}$.

1987. Het Evangelie naar Johannes. Deel 1. Kampen. Kok.

SCHNACKENBURG, R.

1984. The Gospel according to St John. Volume1. (Translated by Kevin Smyth.) Tunbridge Wells, Kent: Burns and Oates.

SCHUDDER, L R 2008. The Qur'ân's evaluation of human nature: An inquiry with a view toward Christian-Muslim dialogue. Reformed Review 61(2) (online):71-80.

SCHUMANN, O.

2002. Jesus the Messiah in Muslim thought. Delhi: ISPCK/HMI.

SMELIK, E.L.

1977. Het Evangelie naar Johannes. Nijkerk: Callenbach. De prediking van het Nieuwe Testament.

STARKEY, P.

1985. Agape: a Christian criterion for truth in the other world religions. International Review of Mission 74(296):425-463.

TAKIM, L.

2004. From conversion to conversation: Interfaith dialogue in Post 9-11 America. The Muslim World 94 (July):343-355.

TOWNE, E.A.

2005. Reason and the more excellent spirit: a reformed reflection on John 3:16. Encounter 66(3):233-253. 
Verster Die liefde van God as aanknopingspunt vir 'n gesprek met Moslems

VAN TILBORG, S.

1993. Imaginative love in John. Leiden: Brill.

VAN Wolde, E.J.

1989. A symiotic analysis of Genesis 2-3: A semiotic theory and method of analysis applied to the story of the Garden of Eden. Assen: Van Gorcum.

WAETJEN, H.C.

2005. The Gospel of the beloved disciple: A work in two editions. London: T. \& T. Clark.

Wessels, A.

1978. De Moslimse naaste: Op weg naar een theologie van de Islam. Kampen: Kok.

ZAHN, T.

1983. Das Evangelium des Johannes. Wuppertal: TVG.

Trefwoorde

Liefde

Seun van God

Moslems

Gesprek
Keywords

Love

Son of God

Muslims

Dialogue 